\title{
Changes to hypothalamic volume and associated subfields during gender-affirming hormone treatment in gender dysphoria
}

\author{
Konadu ME ${ }^{1}$, Reed MB ${ }^{1}$, Kaufmann $\mathrm{U}^{2}$, Handschuh $\mathrm{PA}^{1}$, \\ Spies $\mathrm{M}^{1}$, Spurny-Dworak $\mathrm{B}^{1}$, Klöbl $\mathrm{M}^{1}$, Ritter $\mathrm{V}^{1}$, \\ Godbersen $\mathrm{GM}^{1}$, Seiger $\mathrm{R}^{1}$, Baldinger-Melich $\mathrm{P}^{1}$, \\ Kranz $\mathrm{GS}^{1,3}$, Lanzenberger $\mathrm{R}^{1 *}$
}

\author{
${ }^{1}$ Department of Psychiatry and Psychotherapy, Medical University of Vienna, Austria \\ ${ }^{2}$ Department of Obstetrics and Gynecology, Medical University of Vienna, Austria \\ ${ }^{3}$ Department of Rehabilitation Sciences, The Hong Kong Polytechnic University, Hung Hom, Hong Kong
}

\begin{tabular}{|c|l|}
\hline \multicolumn{2}{|c|}{ Word count } \\
\hline 324 & Abstract \\
\hline 3790 & Manuscript Length \\
\hline \multicolumn{2}{|c|}{ Table: 1, Figure: 1} \\
\hline
\end{tabular}

${ }^{*}$ Correspondence:

Prof. Rupert Lanzenberger, MD PD

Department of Psychiatry and Psychotherapy, Medical University of Vienna, Austria rupert.lanzenberger@meduniwien.ac.at http://www.meduniwien.ac.at/neuroimaging/

Keywords: transgender, gender-affirming hormone treatment, sex steroid hormones, hypothalamus, hypothalamic nuclei, hypothalamic subfields, hypothalamic subunits, transwomen 
medRxiv preprint doi: https://doi.org/10.1101/2022.02.02.22270319; this version posted February 4, 2022. The copyright holder for this preprint (which was not certified by peer review) is the author/funder, who has granted medRxiv a license to display the preprint in It is made available under a CC-BY 4.0 International license.

\section{Abstract}

Sex steroid hormones influence hypothalamic micro- and macrostructure in humans and animal models. Neuroimaging studies have suggested that estrogen and anti-androgen treatment decreases volumes of multiple cortical and subcortical brain areas in transgender individuals, including total hypothalamus volume. Here, we aim to further explore potential effects of gender-affirming hormone treatment (GHT) in transgender individuals on hypothalamic volume by providing additional information on hypothalamic subfields.

38 transgender men (TM) and 15 transgender women (TW), with gender dysphoria (DSM-5), as well as 32 cisgender women (CW) and 21 cisgender men (CM) underwent two magnetic resonance imaging (MRI) measurements with an interval of at least four months (median interval $\mathrm{TM}=134.5$ days (interquartile range (IQR): 126-152.25); TW= 149 days (IQR: 126-178.5); CW= 147 days (IQR: 139.75-170.5); $C M=146$ days (IQR: 132-247)) between both sessions. In transgender individuals GHT, consisting of estrogen and antiandrogen treatment in TW and testosterone treatment in TM, was initiated directly after the first measurement. To assess how GHT interacts with hypothalamic structures, the hypothalamus and its subunits were segmented using FreeSurfer. Subject group $\mathrm{x}$ time interaction effects were evaluated using repeated measures ANCOVA models. The Bonferroni method was used to correct for multiple comparisons.

Significant decreases of total hypothalamic volume and associated subunits were detected in TW after estrogen and anti-androgen treatment compared to cisgender groups. Effects were found in the total hypothalamus volume $\left(p_{\text {corr }}=0.001\right)$, the left and right hypothalamus $\left(p_{\text {corr }}=0.002\right.$ ), the inferior tubular subunit bilaterally (right: $p_{\text {corr }}=0.001$; left: $\left.p_{\text {corr }}=0.001\right)$, the left superior tubular subunit $\left(p_{\text {corr }}=0.003\right)$ the right anterior inferior subunit $\left(p_{\text {corr }}=0.002\right)$, as well as the right anterior superior subunit $\left(p_{\text {corr }}=0.0002\right)$ of the hypothalamus.

Here, we observed significant volumetric effects on the adult human hypothalamus after an interval of at least four months of estrogen and anti-androgen treatment in TW and 
medRxiv preprint doi: https://doi.org/10.1101/2022.02.02.22270319; this version posted February 4, 2022. The copyright holder for this preprint (which was not certified by peer review) is the author/funder, who has granted medRxiv a license to display the preprint in

It is made available under a CC-BY 4.0 International license .

added knowledge on associated subfields. Further studies investigating influences of sex steroid hormones on brain structure and functional connections are still needed.

\section{Introduction}

The hypothalamus is a subcortical structure in the human brain that acts as a neuroendocrine control center of the human body. It is subdivided into several nuclei, each of which exert specific actions (Swaab et al., 1993), ranging from the control of body temperature (Zhao et al., 2017), and energy homeostasis (Timper \& Brüning, 2017), to sexual (Paredes, 2003), and aggressive behavior (Gouveia et al., 2019). Sex steroid hormones are believed to influence brain development in the perinatal brain, as well as in adulthood by so-called "organizational" and "activational" effects (Arnold, 2009). Sex differences in the hypothalamus are thought to mainly be driven by the effects of estradiol (Lenz \& McCarthy, 2010) and have been observed in rodent studies in several hypothalamic substructures including the arcuate nucleus, preoptic area and the medial basal hypothalamus (Brawer et al., 1983; Brawer et al., 1978; Lenz \& McCarthy, 2010). A recent review emphasized that a substructure of the human hypothalamus, the third interstitial nucleus of the anterior hypothalamus (INAH-3), displays the largest difference of human brain volumes between cisgender male and female individuals (Eliot et al., 2021). This is supported by an earlier study, which revealed larger hypothalamus volumes in cisgender men and linked these findings to higher amounts of estrogen and androgen receptor densities in this structure (Goldstein et al., 2001). Interestingly, when analyzing central effects of oral contraceptives (OCP), mainly consisting of estrogens and progestogens (Dragoman, 2014), a reduction of hypothalamic grey matter volume in OCP users compared to naturally cycling women was revealed (Chen et al., 2021). Therefore, an influence of sex steroid hormones on hypothalamic structure could be assumed. Furthermore, it has been found that hypothalamic volumes show variations in affective disorders (Schindler et al., 2012; Schindler et al., 2019). Mood disorders are known to have different prevalence rates in males and females, which in part might be influenced by hormones (Salk et al., 2017). 
medRxiv preprint doi: https://doi.org/10.1101/2022.02.02.22270319; this version posted February 4, 2022. The copyright holder for this preprint (which was not certified by peer review) is the author/funder, who has granted medRxiv a license to display the preprint in It is made available under a CC-BY 4.0 International license.

Considering these aspects, the hypothalamus represents a highly relevant target when investigating the impact of sex steroid hormones on the human living brain.

A unique approach to study direct effects of high dosages of sex steroid hormones on the human brain is to investigate transgender individuals undergoing gender-affirming hormone treatment (GHT) (Kranz et al., 2020). The term "gender dysphoria" (DSM-5), or "gender incongruence" (ICD-11) describes an individual's feeling of incongruence between the experienced gender identification, "gender identity" and the biological gender assigned at birth. GHT typically consists of estrogen and anti-androgen treatment in transgender women (TW; male assigned at birth, with female gender identity) and testosterone treatment in transgender men (TM; female assigned at birth, with male gender identity) (Kranz et al., 2020) and is linked to improved mental health outcomes and reductions in body dissatisfaction (Nguyen et al., 2019).

A previous study by our group investigating the impact of GHT on hypothalamic microstructure assessed by diffusion-weighted imaging (DWI) found androgen-related reductions of the mean diffusivity (MD) in the lateral hypothalamus of TM receiving testosterone replacement therapy for four months (Kranz et al., 2018). These findings suggest a change of hypothalamic microstructure towards proportions found in cisgender men (CM; male assigned at birth, with male gender identity) (Kranz et al., 2018). Another in vivo neuroimaging study investigated structural changes of grey matter volumes before and after four months of GHT in a sample of eight TM and six transgender women. In TM, androgen treatment led to an increase of total brain volume into the direction observed in $\mathrm{CM}$. Anti-androgen and estrogen treatment in TW, on the other hand, led to a decline of total brain and hypothalamus volumes towards values typically found in cisgender women (CW; female assigned at birth, with female gender identity) (Pol et al., 2006). Also, in post-mortem studies of transgender persons who have undergone GHT in their lives, the INAH-3 in TW has been found to be comparable to that of $\mathrm{CW}$ in terms of volume and number of neurons. In one TM subject the INAH-3 size was comparable to sizes of CM (Garcia-Falgueras \& Swaab, 2008). 
medRxiv preprint doi: https://doi.org/10.1101/2022.02.02.22270319; this version posted February 4, 2022. The copyright holder for this preprint (which was not certified by peer review) is the author/funder, who has granted medRxiv a license to display the preprint in It is made available under a CC-BY 4.0 International license.

Neuroimaging studies investigating the effects of GHT on the brain, specifically on the hypothalamus, are scarce and mostly underpowered. Our study aims to further elucidate the potential link between sex steroid hormones and morphologic changes of the adult human brain. Therefore, we examined hypothalamic volume, including its subfields before and after four months of GHT in transgender individuals. Based on existing findings, we hypothesized a decrease of total hypothalamic volume in TW after four months of GHT.

\section{Methods}

\subsection{Sample}

The data analyzed was combined from two larger studies conducted by our group and partly has been published earlier addressing other research questions (Baldinger-Melich et al., 2020; Hahn et al., 2016; Kranz et al., 2014; Kranz et al., 2018; Kranz et al., 2017; Seiger et al., 2016; Spies et al., 2016). For this analysis, we considered data from 125 right-handed subjects who underwent two magnetic resonance imaging (MRI) measurements in a longitudinal design. 19 subjects had to be excluded before analysis because of poor MRI data quality. The resulting sample of 106 participants included into the final analysis, consisted of $32 \mathrm{CW}$ (mean age \pm standard deviation $(S D)=25.14 \pm 6.06$ ), $38 \mathrm{TM}$ (mean age $\pm \mathrm{SD}=25.94 \pm 6.49), 21 \mathrm{CM}$ (mean age $\pm \mathrm{SD}=26.62 \pm 6.41)$ and $15 \mathrm{TW}$ (mean age $\pm \mathrm{SD}=$ $26.26 \pm 4.26)$ participants. Two MRI measurements were performed in all subjects with a median interval of 134.5 days in TM (interquartile range (IQR): 126-152.25), 149 days in TW (IQR: 126-178.5), 147 days in CW (IQR: 139.75-170.5) and 146 days in CM (IQR: 132-247). GHT was initiated in transgender individuals directly after the first measurement.

Transgender subjects were recruited from the transgender outpatient unit of the Department of Obstetrics and Gynecology, Unit for Gender Identity Disorder, Medical University of Vienna. A diagnosis of gender dysphoria according to the Diagnostic and Statistical Manual of Mental Disorders (DSM)-5, designated as gender incongruence in the International Classification of Diseases (ICD)-11, and the desire for GHT had to be present for enrollment. Cisgender subjects were recruited via online media as well as flyers on 
medRxiv preprint doi: https://doi.org/10.1101/2022.02.02.22270319; this version posted February 4, 2022. The copyright holder for this preprint (which was not certified by peer review) is the author/funder, who has granted medRxiv a license to display the preprint in

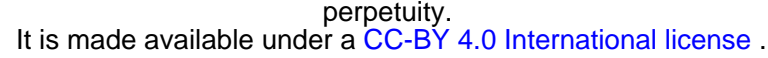

designated message boards in Vienna and the Medical University of Vienna. Participants with presence or history of a physical, neurological, or psychiatric disorder (cisgender subjects) or a major DSM-5 Axis-I comorbidity (transgender subjects), abnormal blood values or anomalies in clinical examinations were excluded from the study. Additionally, pregnancy, breastfeeding, substance abuse (except smoking), steroid hormone treatment within six months prior to study start, and contraindications for the participation in MRI measurements were set as exclusion criteria.

Both studies were approved by the Ethics Committee of the Medical University of Vienna (EK number study 1: 1104/2015, study: 644/2010) and registered at ClinicalTrials.gov (ClinicalTrials.gov Identifier study 1: NCT02715232; study 2: NCT01292785). Every subject gave written informed consent, was insured and received financial reimbursement for participation. All procedures performed during both studies were in accordance with the Helsinki declaration and latest revisions.

\subsection{Study Design and treatment protocol}

Both studies were conducted as longitudinal mono-center studies. All participants underwent a baseline MRI scan and a second MRI scan after an interval of at least four months (median intervals see section 3.1). Directly after the first MRI measurement GHT was initiated in transgender subjects. Checkups of the hormone treatment were performed regularly for all transgender participants at the Department of Obstetrics and Gynecology, Unit of Gender Identity Disorder of the Medical University of Vienna.

TM received either $1000 \mathrm{mg}$ of testosterone undecanoate administration every 8-12 weeks $\left(\right.$ Nebido $^{\circledR}, 250 \mathrm{mg} / \mathrm{ml}, 4 \mathrm{ml}$ vial, applied intramuscularly) or $50 \mathrm{mg}$ testosterone cream or gel applied transdermally $\left(\right.$ Testoge $^{\circledR}$, Testavan $\left.{ }^{\circledR}\right)$. Additionally, in some cases $75 \mu \mathrm{g}$ desogestrel (Moniq Gynial ${ }^{\circledR}$ ) per day or triptorelin acetate as a depot (Decapepty ${ }^{\circledR}$ ) was given every 4-5 weeks. TW received 25 to $50 \mathrm{mg}$ cyproterone acetate daily (Androcur ${ }^{\circledR}$ ) and estradiol $2 \times 2 \mathrm{mg}$ per day $\left(\right.$ Estrofem $\left.^{\circledR}\right)$ or estradiol $1.5-3 \mathrm{mg}$ per day applied transdermally $\left(\right.$ Estrogel ${ }^{\circledR}$ ) was administered. In some cases, triptorelin acetate as a depot (Decapepty $\left.{ }^{\circledR}\right)$ 
medRxiv preprint doi: https://doi.org/10.1101/2022.02.02.22270319; this version posted February 4, 2022. The copyright holder for this preprint (which was not certified by peer review) is the author/funder, who has granted medRxiv a license to display the preprint in It is made available under a CC-BY 4.0 International license.

was given every 4-5 weeks. Some participants additionally received progesterone (Arefam $\left.{ }^{\circledR}\right)$ 100-200mg per day. If extensive hair loss occurred, $2.5 \mathrm{mg}$ of an alpha-5-reductase-inhibitor (Finasterid) every second day was prescribed.

\subsection{Hormonal blood sampling}

Hormonal blood samples were drawn at each MRI measurement from all participants. The plasma levels of dehydroepiandrosterone sulfate (DHEAS), $17 \beta$-estradiol, follicle-stimulating hormone $(\mathrm{FSH})$, luteinizing hormone $(\mathrm{LH})$, progesterone, sex hormone-binding globulin (SHBG) and testosterone were analyzed by the Department of Laboratory Medicine, Medical University of Vienna (http://www.kimcl.at). These hormonal values have been included in our statistical analysis to correct for different hormonal treatment regimens transgender participants received, as well as for unknown effects of other relevant hormonal values.

\subsection{Data acquisition}

As the data analyzed was combined from two studies conducted by our group, MRI measurements were performed using two separate 3 Tesla MRI scanners (study 1: Siemens Magnetom Prisma, Erlangen, Germany/ study 2: Siemens Tim Trio, Erlangen, Germany) with a 64-channel (study 1) and 32-channel (study 2) head coil and a T1 weighted magnetization prepared rapid gradient echo (MPRAGE) sequence (study $1: \mathrm{TE}=2.91 \mathrm{~ms} ; \mathrm{TR}=2000 \mathrm{~ms} ; \mathrm{TI}=$ 900ms; $\alpha=9^{\circ} ; 192$ slices; $240 \times 256$ matrix; $1 \times 1 \times 1 \mathrm{~mm}^{3}$ voxel size/ study $2: \mathrm{TE}=4.21 \mathrm{~ms}$; $\mathrm{TR}=2300 \mathrm{~ms} ; \mathrm{Tl}=900 \mathrm{~ms}, \alpha=9^{\circ} ; 160$ slices; $240 \times 256$ matrix; $1.1 \times 1 \times 1 \mathrm{~mm}^{3}$ voxel size total acquisition time $7 \mathrm{~min}, 46 \mathrm{~s}$ ). LongCombat was employed to correct for means and variances of the residuals across different scanners in this longitudinal setting (Beer et al., 2020). Using this method, the group and time differences were set to be maintained, while the scanner differences were harmonized. 
medRxiv preprint doi: https://doi.org/10.1101/2022.02.02.22270319; this version posted February 4, 2022. The copyright holder for this preprint (which was not certified by peer review) is the author/funder, who has granted medRxiv a license to display the preprint in

\subsection{Data processing}

A visual quality check of the MRI data was performed. Subjects were processed with the standard pipeline of the FreeSurfer software suit (http://surfer.nmr.mgh.harvard.edu/, version 7.2) (Dale et al., 1999; Fischl et al., 1999). Our study model consists of measurements at two timepoints, therefore the longitudinal stream was used afterwards (Reuter et al., 2012). Subsequently, the hypothalamus and its subfields were segmented using the recently presented automated segmentation tool for the hypothalamus and associated subfields, which is distributed with FreeSurfer (Billot et al., 2020). In this tool hypothalamic subnuclei are assigned to five hypothalamic subunits on each side, which are classified according to Bocchetta et al. and Makris et al. (Bocchetta et al., 2015; Makris et al., 2013). The automated segmentation has been checked visually by a trained neuroscientist.

\subsection{Statistical analysis}

Statistical analysis was performed using SPSS version 25 for Windows (SPSS Inc., Chicago; Illinois; www.spss.com). Repeated measures analysis of covariance (rmANCOVA) was used to investigate the influence of GHT on hypothalamic volumes. Group (CW, TM, CM, TW) was used as between-subject-factor, whereas time (M1, M2) was included as the within-subjectfactor. The interaction of group $x$ time was examined in a stepwise approach. A separate analysis of the total hypothalamic volume was performed, if significant each side was analyzed, and if significant again, each subunit in the respective side was tested. To correct for different hormonal treatment regimens, as well as effects of other relevant hormonal values, we included DHEAS, SHBG, FSH, LH, progesterone, estradiol and testosterone of each participant into our analysis as covariates. To reduce the dimensionality of these values, a principal component analysis (PCA) was applied and the first two components explaining $>98 \%$ of the total variance were integrated into our statistical model as covariates. The total intracranial volume (TIV) was also included as a covariate into our model (Eliot et al., 2021). The Bonferroni method was used to correct for multiple comparisons of regions and post-hoc tests included in each analysis. 
medRxiv preprint doi: https://doi.org/10.1101/2022.02.02.22270319; this version posted February 4, 2022. The copyright holder for this preprint (which was not certified by peer review) is the author/funder, who has granted medRxiv a license to display the preprint in

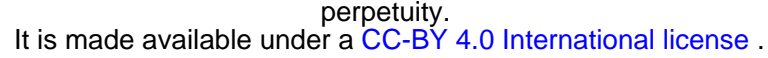

\section{Results}

Analyses revealed an interaction effect of group $x$ time in the total volume of the hypothalamus $\left(F=6.281, p_{\text {corr }}=0.001\right)$. When analyzing the left $\left(F=6.397, p_{\text {corr }}=0.002\right)$ and right $\left(F=6.080, p_{\text {corr }}=0.002\right)$ hypothalamus, again significant interaction effects of group $x$ time were found. In the single nuclei, significant interaction effects of group $x$ time were found in the left inferior tubular subunit $\left(F=7.267, p_{\text {corr }}=0.001\right)$, right inferior tubular subunit $(F=7.294$, $\left.p_{\text {corr }}=0.001\right)$, left superior tubular subunit $\left(F=6.689, p_{\text {corr }}=0.003\right)$, right anterior superior subunit $\left(F=7.025, p_{\text {corr }}=0.0002\right)$ and right anterior inferior subunit $\left(F=7.387, p_{\text {corr }}=0.002\right)$. Post-hoc pairwise comparison between M1 and M2 in each group displayed a significant volume decrease in these regions in the TW group compared to cisgender groups (see Fig.1). All results reported were significant after correcting for multiple comparisons using the Bonferroni method for the number of regions and post-hoc tests included in each analysis. In CW smaller hypothalamus volumes have been observed at the second measurement compared to the first measurement, which, however, did not reach significance. Also, in TM and $\mathrm{CM}$ no significant differences between the two timepoints were detected. Significant results found in TW are summarized in Table 1.

\begin{tabular}{lccc}
\hline Region & F-value & $\begin{array}{c}\text { p-value } \\
\text { (corr.) }\end{array}$ & post-hoc \\
\hline \hline Whole Hypothalamus & 6.281 & 0.001 & $\downarrow$ \\
Left Hypothalamus & 6.397 & 0.002 & $\downarrow$ \\
Right Hypothalamus & 6.080 & 0.002 & $\downarrow$ \\
Left Inferior Tubular Subunit & 7.267 & 0.001 & $\downarrow$ \\
Right Inferior Tubular Subunit & 7.294 & 0.001 & $\downarrow$ \\
Left Superior Tubular Subunit & 6.689 & 0.003 & $\downarrow$ \\
Right Anterior Superior Subunit & 7.025 & 0.0002 & $\downarrow$ \\
Right Anterior Inferior Subunit & 7.387 & 0.002 & $\downarrow$ \\
\hline
\end{tabular}

Table 1: Significant results of hypothalamic volume and associated subfields in TW. F-values and corrected p-values of significant decreases in each region in transgender women (TW) after an interval of at least four months of estrogen and anti-androgen treatment are presented. $(\downarrow)$ represents post hoc decreases. 

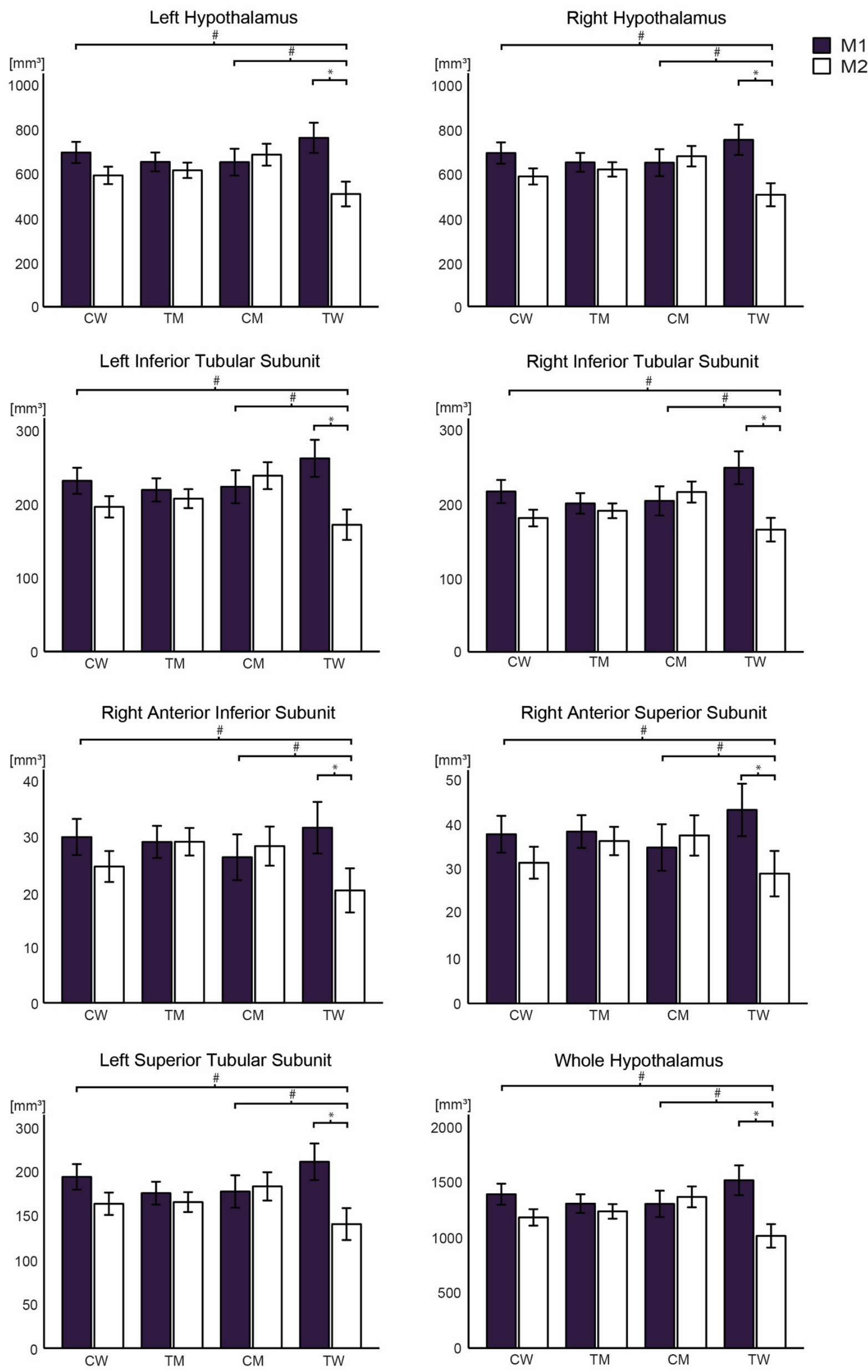
medRxiv preprint doi: https://doi.org/10.1101/2022.02.02.22270319; this version posted February 4, 2022. The copyright holder for this preprint (which was not certified by peer review) is the author/funder, who has granted medRxiv a license to display the preprint in It is made available under a CC-BY 4.0 International license.

Figure 1: Decreased volumes of the hypothalamus and associated subfields in TW after an interval of at least four months of GHT. Post-hoc comparisons between baseline MRI (M1) and MRI after an interval of at least four months (M2) in each subject group (CW, TM, CM, TW). Transgender participants received GHT directly after the first measurement. A significant reduction of hypothalamic volumes as well as subfields is given in the TW group in comparison to cisgender groups (whole hypothalamus, left and right hypothalamus, left and right inferior tubular subunit, right anterior inferior subunit, right anterior superior subunit, left superior tubular subunit). $\left({ }^{*}\right)$ reports significant results corrected for multiple comparison, while (\#) represents interaction effects between groups. The error bars represent $95 \%$ confidence interval. $\mathrm{CW}=$ cisgender women, $\mathrm{TM}=$ transgender men, $\mathrm{CM}=$ cisgender men, $\mathrm{TW}=$ transgender women. 
medRxiv preprint doi: https://doi.org/10.1101/2022.02.02.22270319; this version posted February 4, 2022. The copyright holder for this preprint (which was not certified by peer review) is the author/funder, who has granted medRxiv a license to display the preprint in

It is made available under a CC-BY 4.0 International license .

\section{Discussion}

In this study, the potential effects of estrogen and anti-androgen treatment on total hypothalamic volume as well as associated subfields were examined before compared to after an interval of at least four months of GHT in transgender individuals. Analyses were performed across four groups comprising TW and TM receiving GHT as well as untreated healthy controls (CW, CM). Group $x$ time interaction effects were elucidated using repeated measures ANCOVA models. Here, we found significant reductions of hypothalamic volumes in TW receiving estrogen and anti-androgen treatment. Effects in the total hypothalamus have been attributed to the anterior and tubular subunits of the hypothalamus - more precisely, to the inferior tubular subunit bilaterally, the left superior tubular subunit, the right anterior inferior subunit, as well as the right anterior superior subunit.

Our result, showing a reduction in total hypothalamus volume in TW after at least four months of GHT are in line with an earlier finding of reduced total hypothalamic volume after four months of estrogen and anti-androgen treatment in TW (Pol et al., 2006). Though relevant, this study comprised a small sample size consisting of six TW and eight TM, presented uncorrected p-values and used an MRI segmentation method which was not directly comparable to the method used in our investigation. We were able to extend these findings by analyzing a larger sample size, presenting corrected p-values and using an automated MRI segmentation method, which aims to provide future comparability. Underlining our observations, findings showing volume reductions in multiple cortical and subcortical brain structures in TW after estrogen and anti-androgen treatment have been repeatedly published (Seiger et al., 2016; Zubiaurre-Elorza et al., 2014). In our study CW showed smaller hypothalamus volumes at the second MRI measurement compared to the first measurement. Although these results were not significant, it is interesting to note that Pol et al. made the same observations in their study (Pol et al., 2006). Estrogen and progesterone concentrations fluctuate during different phases of the menstrual cycle (Farage et al., 2009). These naturally occurring variations of hormone concentrations in the human body could affect brain morphometry as well. In fact, an exploratory analysis of naturally 
medRxiv preprint doi: https://doi.org/10.1101/2022.02.02.22270319; this version posted February 4, 2022. The copyright holder for this preprint (which was not certified by peer review) is the author/funder, who has granted medRxiv a license to display the preprint in It is made available under a CC-BY 4.0 International license.

cycling women revealed volumetric differences of the total hypothalamus during different menstrual cycle phases (Chen et al., 2021). Also other studies showed variations of volumetric findings of the human brain in different menstrual cycle phases of naturally cycling women (De Bondt et al., 2013; Protopopescu et al., 2008). The cisgender women examined in our study could therefore have been in different phases of their natural menstrual cycle, which could reflect the volumetric differences found at the two timepoints and should be subject of future investigations.

A study exploring the effects of OCPs on human brain structure, reported smaller hypothalamic volume in healthy $\mathrm{CW}$ with $\mathrm{OCP}$ intake compared to naturally cycling $\mathrm{CW}$ (Chen et al., 2021). OCP mostly consists of estrogens and progestogens (Dragoman, 2014). Hence, the continuous intake of exogenously supplied estrogens in OCP users could have demonstrated a similarly decreasing effect on hypothalamic volume as discovered in the present study. Nevertheless, OCP use and estrogen treatment in GHT may not be directly comparable. Moreover, the authors provided no exact information on which kind of OCP was used. Therefore, drawing a comparison remains challenging. When focusing on other hypothalamic measures a study investigated effects of combined OCPs, consisting of estrogens and progestogens (Dragoman, 2014), in CW. Here, in the pill-free-phase transient microstructural and metabolic changes were observed in the hypothalamus (Baroncini et al., 2010). This phase is accompanied by a cessation of exogenously supplied estrogens and therefore a withdrawal of negative feedback mechanisms on the hypothalamo-pituitarygonadal axis. Thus, an influencing impact due to differences in sex steroid hormone concentrations on hypothalamic measures could be assumed. The authors concluded that the elucidated changes might involve neuronal or glial remodeling of the hypothalamus in connection with gonadal axis activation (Baroncini et al., 2010), which in turn could take part in the explanation of our findings.

Studies investigating the impact of sex steroid hormones on brain structure revealed effects which occur in the developing brain and remain permanent, as well as influences in adulthood that are viewed as reversible. These are referred to as "organizational" or 
medRxiv preprint doi: https://doi.org/10.1101/2022.02.02.22270319; this version posted February 4, 2022. The copyright holder for this preprint (which was not certified by peer review) is the author/funder, who has granted medRxiv a license to display the preprint in

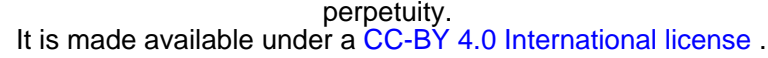

"activational" effects (Arnold, 2009; Gillies \& McArthur, 2010). Activational effects on the hypothalamus have been elucidated in animal models. For example, in an ovine MRI study, baseline hypothalamic volume differences in males and females, which were described as sexually dimorphic, diminished after one month of gonadectomy (Barrière et al., 2019). Moreover, in earlier studies gonadectomized male mice which received estrogen and progesterone treatment showed significant reductions of volumes in hypothalamic nuclei in the medial preoptic area (Bloch \& Gorski, 1988), as well as in the supraoptic area and the arcuate nucleus (Bloch \& Gorski, 1988; Brawer et al., 1980). In "hormonally healthy" male mice estrogen and progesterone treatment did not lead to decreases in hypothalamic nuclei, therefore the authors deduced a protecting impact of accompanying high androgen levels on hypothalamic substructure (Bloch \& Gorski, 1988). Taken together these findings might indicate that the effects in our study may firstly be referred to as activational effects and secondly, these effects might not only be present due to high estrogen levels but also because of simultaneously low testosterone levels. This hypothesis would be plausible considering an earlier described theory of a general anabolic and anticatabolic effect of testosterone on brain structure (Kranz et al., 2020; Zubiaurre-Elorza et al., 2014).

Another interesting aspect is how these volumetric findings could be functionally relevant in our study sample. As mentioned before the hypothalamus is known to be tightly integrated in a range of vital human functions which include endocrine and autonomic functions, as well as behavioral and emotional aspects. When considering the findings of our study, mainly the anterior and tubular regions of the hypothalamus were affected. This includes hypothalamic nuclei which are integrated in e.g., stress, arousal, sexual behavior, aggression, and sleep (Saper \& Lowell, 2014). Interestingly, these hypothalamic nuclei were largely found to be influenced by estrogens in human and animal studies. To name a few, the ventromedial nucleus and PVN were attributed to be involved in the regulation of arousal and affective responses and have been found to be affected by estrogens during the menstrual cycle of CWs in an fMRI study (Goldstein et al., 2010; Goldstein et al., 2005). Moreover, the ventromedial nucleus is involved in aggressive behavior and was detected to play a 
medRxiv preprint doi: https://doi.org/10.1101/2022.02.02.22270319; this version posted February 4, 2022. The copyright holder for this preprint (which was not certified by peer review) is the author/funder, who has granted medRxiv a license to display the preprint in It is made available under a CC-BY 4.0 International license .

substantial part in male and female aggression by expression of the estrogen receptor- $\alpha$ in mice (Hashikawa et al., 2017; Lee et al., 2014). Furthermore, estrogen has been found to influence dendritic spine density, a measure of synaptic connectivity, of the ventromedial hypothalamus in projection areas to the periaqueductal gray, which is crucially involved in female sexual behavior in a rat study (Calizo \& Flanagan-Cato, 2002; Flanagan-Cato et al., 2001). Viewed from another perspective, transgender individuals revealed behavioral and hormonal changes during the course of GHT that may be related to functions of the mentioned nuclei. In that context, three months of estrogen and anti-androgen treatment was found to increase adrenocorticotropic hormone (ACTH) and cortisol levels after corticotropinreleasing hormone $(\mathrm{CRH})$ administration in TW, which are values involved in stress response (Fuss et al., 2019). Moreover, sexual desire decreased during the first three months of GHT in TW, whereas it changed to be higher than baseline after 36 months of GHT (Defreyne et al., 2020). However, a link between aggression and GHT in transgender individuals remains inconclusive (Defreyne et al., 2019; Defreyne et al., 2018; Kristensen et al., 2021). Direct relationships between these relevant but exemplary presented structural and functional changes are difficult to pinpoint. Further studies investigating functional connections of hypothalamic subnuclei in transgender individuals would contribute to deepen the knowledge on the influence of sex steroid hormones on the human brain and potentially provide important information on neuronal changes during GHT to transgender individuals.

Some limitations of this study should be considered. The hypothalamus is a small structure in the human brain which exhibits low image contrast in MRI. Therefore, volumetric data in general remains scarce. With advances in this field however, improved analysis was performed and automated tools for MRI segmentation were presented, providing reproducibility and better comparability (Billot et al., 2020). In our study, we used the first automated tool, which performs segmentation of the whole hypothalamus as well as its subfields in T1-weighted MRI brain scans accurately and robustly (Billot et al., 2020). The hypothalamus, moreover, is anatomically located next to the third ventricle (Swaab et al., 1993). Studies investigating cortical and subcortical structures in transgender individuals 
medRxiv preprint doi: https://doi.org/10.1101/2022.02.02.22270319; this version posted February 4, 2022. The copyright holder for this preprint (which was not certified by peer review) is the author/funder, who has granted medRxiv a license to display the preprint in It is made available under a CC-BY 4.0 International license .

found increased ventricle volumes in TW after four months of estrogen and anti-androgen treatment (Pol et al., 2006; Seiger et al., 2016; Zubiaurre-Elorza et al., 2014). These changes are discussed to be caused by surrounding grey or white matter structure variances during GHT (Seiger et al., 2016), which we cannot exclude being present in our findings. Nevertheless, we have tried to account for this effect by including TIV into our analysis. In addition, we examined data from two different studies conducted by our group, therefore our study sample was measured on two different $3 T$ MRI devices. We corrected for multiscanner imaging data using LongCombat (Beer et al., 2020), but cannot exclude influential factors. The effects seen in our study are most likely attributed to the estrogen and antiandrogen treatment TW received. However, we cannot exclude other confounding factors such as behavioral or mood changes as well as potential influences of other hormonal values. Nevertheless, we tried to rule out hormonal disruptors by adding relevant values into our statistic model.

\section{Conclusion}

Taken together, our results point toward a significant volumetric effect on the human hypothalamus and associated subfields after estrogen and anti-androgen treatment administered for an interval of at least four months in TW participants. Changes in hypothalamic volume have been mainly found in the anterior and tubular subfields of the hypothalamus - specifically, in the inferior tubular subunit bilaterally, the left superior tubular subunit, the right anterior inferior subunit, as well as the right anterior superior subunit. However, further studies investigating the effect of sex steroid hormones on human brain structure and functional connections of the hypothalamus and its subunits are needed to interpret these findings in a clinical sense. 
medRxiv preprint doi: https://doi.org/10.1101/2022.02.02.22270319; this version posted February 4, 2022. The copyright holder for this preprint (which was not certified by peer review) is the author/funder, who has granted medRxiv a license to display the preprint in It is made available under a CC-BY 4.0 International license.

\section{Conflict of Interest}

Without relevance to this work, R. Lanzenberger received travel grants/financial compensation for conference talks within the last three years from Bruker BioSpin MR and Heel. He was a consultant for Ono Pharmaceutical. He received funding for clinical research using PET/MR from Siemens Healthcare and is involved in the start-up company BM Health $\mathrm{GmbH}$ since 2019 as a shareholder.

\section{Author Contributions}

The study was designed by RL and GSK. Medical support was provided by UK, PAH, MS, GMG, PBM and MEK. MRI measurements were performed by MBR, RS, BSD and MK. Administrative support was provided by VR. FreeSurfer analyses were performed by RS and BSD. Statistical analyses were conducted by MBR. MEK wrote the first draft of the manuscript. All authors contributed to the interpretation of the results, revised the manuscript and approved the final version.

\section{9. $\quad$ Funding}

This research was funded in whole, or in part, by the Austrian Science Fund (FWF) [KLI504 and P23021, PI: Lanzenberger Rupert]. For the purpose of open access, the author has applied a CC BY public copyright licence to any Author Accepted Manuscript version arising from this submission. M.B. Reed and M. Klöbl received funding from a DOC Fellowship, Austrian Academy of Science. This research was supported by the grant "Interdisciplinary translational brain research cluster (ITHC) with highfield MR" from the Federal Ministry of Science, Research and Economy (BMWFW), Austria. M.E. Konadu received support by the Austrian National Union of Students for conducting this analysis.

\section{Acknowledgments}

We thank the graduated team members and the diploma students of the Neuroimaging Labs (NILs, headed by R. Lanzenberger), the members of the High Field MR Center, as well as 
medRxiv preprint doi: https://doi.org/10.1101/2022.02.02.22270319; this version posted February 4, 2022. The copyright holder for this preprint (which was not certified by peer review) is the author/funder, who has granted medRxiv a license to display the preprint in It is made available under a CC-BY 4.0 International license .

the clinical colleagues from the Department of Psychiatry and Psychotherapy of the Medical University of Vienna for clinical and/or administrative support, especially S. Kasper, K. Papageorgiou, G. Gryglewski, T. Vanicek, M. Hienert, J. Unterholzner, A. Komorowski. Also, we would like to express our special thanks to the participants of the study, as it was their willingness to participate that made this study possible.

\section{Data Availability Statement}

For reasons of data protection, the data is available on reasonable request from the corresponding author. 
medRxiv preprint doi: https://doi.org/10.1101/2022.02.02.22270319; this version posted February 4, 2022. The copyright holder for this preprint (which was not certified by peer review) is the author/funder, who has granted medRxiv a license to display the preprint in perpetuity.

It is made available under a CC-BY 4.0 International license .

\section{References}

Arnold, A. P. (2009). The organizational-activational hypothesis as the foundation for a unified theory of sexual differentiation of all mammalian tissues. Horm Behav, 55(5), 570-578. https://doi.org/10.1016/j.yhbeh.2009.03.011

Baldinger-Melich, P., Urquijo Castro, M. F., Seiger, R., Ruef, A., Dwyer, D. B., Kranz, G. S., Klöbl, M., Kambeitz, J., Kaufmann, U., Windischberger, C., Kasper, S., Falkai, P., Lanzenberger, R., \& Koutsouleris, N. (2020). Sex Matters: A Multivariate Pattern Analysis of Sex- and Gender-Related Neuroanatomical Differences in Cis- and Transgender Individuals Using Structural Magnetic Resonance Imaging. Cereb Cortex, 30(3), 1345-1356. https://doi.org/10.1093/cercor/bhz170

Baroncini, M., Jissendi, P., Catteau-Jonard, S., Dewailly, D., Pruvo, J. P., Francke, J. P., \& Prevot, V. (2010). Sex steroid hormones-related structural plasticity in the human hypothalamus. Neuroimage, 50(2), 428-433. https://doi.org/10.1016/j.neuroimage.2009.11.074

Barrière, D. A., Ella, A., Adriaensen, H., Roselli, C. E., Chemineau, P., \& Keller, M. (2019). In vivo magnetic resonance imaging reveals the effect of gonadal hormones on morphological and functional brain sexual dimorphisms in adult sheep. Psychoneuroendocrinology, 109, 104387. https://doi.org/10.1016/j.psyneuen.2019.104387

Beer, J. C., Tustison, N. J., Cook, P. A., Davatzikos, C., Sheline, Y. I., Shinohara, R. T., \& Linn, K. A. (2020). Longitudinal ComBat: A method for harmonizing longitudinal multi-scanner imaging data. Neuroimage, 220, 117129. https://doi.org/https://doi.org/10.1016/j.neuroimage.2020.117129

Billot, B., Bocchetta, M., Todd, E., Dalca, A. V., Rohrer, J. D., \& Iglesias, J. E. (2020). Automated segmentation of the hypothalamus and associated subunits in brain MRI. Neuroimage, 223, 117287. https://doi.org/https://doi.org/10.1016/j.neuroimage.2020.117287

Bloch, G. J., \& Gorski, R. A. (1988). Estrogen/progesterone treatment in adulthood affects the size of several components of the medial preoptic area in the male rat. J Comp Neurol, 275(4), 613-622. https://doi.org/10.1002/cne.902750409

Bocchetta, M., Gordon, E., Manning, E., Barnes, J., Cash, D. M., Espak, M., Thomas, D. L., Modat, M., Rossor, M. N., Warren, J. D., Ourselin, S., Frisoni, G. B., \& Rohrer, J. D. (2015). Detailed volumetric analysis of the hypothalamus in behavioral variant frontotemporal dementia. Journal of Neurology, 262(12), 2635-2642. https://doi.org/10.1007/s00415-015-7885-2

Brawer, J., Schipper, H., \& Robaire, B. (1983). Effects of long term androgen and estradiol exposure on the hypothalamus. Endocrinology, 112(1), 194-199. https://doi.org/10.1210/endo-112-1-194

Brawer, J. R., Naftolin, F., Martin, J., \& Sonnenschein, C. (1978). Effects of a single injection of estradiol valerate on the hypothalamic arcuate nucleus and on reproductive function in the female rat. Endocrinology, 103(2), 501-512. https://doi.org/10.1210/endo-103-2-501

Brawer, J. R., Schipper, H., \& Naftolin, F. (1980). Ovary-dependent degeneration in the hypothalamic arcuate nucleus. Endocrinology, 107(1), 274-279. https://doi.org/10.1210/endo-107-1-274

Calizo, L. H., \& Flanagan-Cato, L. M. (2002). Estrogen-induced dendritic spine elimination on female rat ventromedial hypothalamic neurons that project to the periaqueductal gray. J Comp Neurol, 447(3), 234-248.

https://doi.org/10.1002/cne.10223 
medRxiv preprint doi: https://doi.org/10.1101/2022.02.02.22270319; this version posted February 4, 2022. The copyright holder for this preprint (which was not certified by peer review) is the author/funder, who has granted medRxiv a license to display the preprint in perpetuity.

It is made available under a CC-BY 4.0 International license .

Chen, K. X., Worley, S., Foster, H., Edasery, D., Roknsharifi, S., Ifrah, C., \& Lipton, M. L. (2021). Oral contraceptive use is associated with smaller hypothalamic and pituitary gland volumes in healthy women: A structural MRI study. PLoS One, 16(4), e0249482. https://doi.org/10.1371/journal.pone.0249482

Dale, A. M., Fischl, B., \& Sereno, M. I. (1999). Cortical surface-based analysis. I. Segmentation and surface reconstruction. Neuroimage, 9(2), 179-194. https://doi.org/10.1006/nimg.1998.0395

De Bondt, T., Jacquemyn, Y., Van Hecke, W., Sijbers, J., Sunaert, S., \& Parizel, P. M. (2013). Regional gray matter volume differences and sex-hormone correlations as a function of menstrual cycle phase and hormonal contraceptives use. Brain Res, 1530, 22-31.

https://doi.org/10.1016/j.brainres.2013.07.034

Defreyne, J., Elaut, E., Kreukels, B., Fisher, A. D., Castellini, G., Staphorsius, A., Den Heijer, M., Heylens, G., \& T'Sjoen, G. (2020). Sexual Desire Changes in Transgender Individuals Upon Initiation of Hormone Treatment: Results From the Longitudinal European Network for the Investigation of Gender Incongruence. J Sex Med, 17(4), 812-825. https://doi.org/10.1016/j.jsxm.2019.12.020

Defreyne, J., Kreukels, B., T'Sjoen, G., Staphorsius, A., Den Heijer, M., Heylens, G., \& Elaut, E. (2019). No correlation between serum testosterone levels and state-level anger intensity in transgender people: Results from the European Network for the Investigation of Gender Incongruence. Horm Behav, 110, 2939. https://doi.org/10.1016/j.yhbeh.2019.02.016

Defreyne, J., T'Sjoen, G., Bouman, W. P., Brewin, N., \& Arcelus, J. (2018). Prospective Evaluation of Self-Reported Aggression in Transgender Persons. J Sex Med, 15(5), 768-776. https://doi.org/10.1016/j.jsxm.2018.03.079

Dragoman, M. V. (2014). The combined oral contraceptive pill -- recent developments, risks and benefits. Best Pract Res Clin Obstet Gynaecol, 28(6), 825-834. https://doi.org/10.1016/j.bpobgyn.2014.06.003

Eliot, L., Ahmed, A., Khan, H., \& Patel, J. (2021). Dump the "dimorphism": Comprehensive synthesis of human brain studies reveals few male-female differences beyond size. Neurosci Biobehav Rev, 125, 667-697. https://doi.org/10.1016/..neubiorev.2021.02.026

Farage, M. A., Neill, S., \& MacLean, A. B. (2009). Physiological changes associated with the menstrual cycle: a review. Obstet Gynecol Surv, 64(1), 58-72. https://doi.org/10.1097/OGX.0b013e3181932a37

Fischl, B., Sereno, M. I., \& Dale, A. M. (1999). Cortical surface-based analysis. II: Inflation, flattening, and a surface-based coordinate system. Neuroimage, 9(2), 195-207. https://doi.org/10.1006/nimg.1998.0396

Flanagan-Cato, L. M., Calizo, L. H., \& Daniels, D. (2001). The synaptic organization of $\mathrm{VMH}$ neurons that mediate the effects of estrogen on sexual behavior. Horm Behav, 40(2), 178-182. https://doi.org/10.1006/hbeh.2001.1679

Fuss, J., Claro, L., Ising, M., Biedermann, S. V., Wiedemann, K., Stalla, G. K., Briken, P., \& Auer, M. K. (2019). Does sex hormone treatment reverse the sexdependent stress regulation? A longitudinal study on hypothalamus-pituitaryadrenal (HPA) axis activity in transgender individuals.

Psychoneuroendocrinology, 104, 228-237. https://doi.org/10.1016/i.psyneuen.2019.02.023

Garcia-Falgueras, A., \& Swaab, D. F. (2008). A sex difference in the hypothalamic uncinate nucleus: relationship to gender identity. Brain, 131(Pt 12), 31323146. https://doi.org/10.1093/brain/awn276 
medRxiv preprint doi: https://doi.org/10.1101/2022.02.02.22270319; this version posted February 4, 2022. The copyright holder for this preprint (which was not certified by peer review) is the author/funder, who has granted medRxiv a license to display the preprint in perpetuity.

It is made available under a CC-BY 4.0 International license .

Gillies, G. E., \& McArthur, S. (2010). Estrogen actions in the brain and the basis for differential action in men and women: a case for sex-specific medicines. Pharmacol Rev, 62(2), 155-198. https://doi.org/10.1124/pr.109.002071

Goldstein, J. M., Jerram, M., Abbs, B., Whitfield-Gabrieli, S., \& Makris, N. (2010). Sex differences in stress response circuitry activation dependent on female hormonal cycle. J Neurosci, 30(2), 431-438. https://doi.org/10.1523/jneurosci.3021-09.2010

Goldstein, J. M., Jerram, M., Poldrack, R., Ahern, T., Kennedy, D. N., Seidman, L. J., \& Makris, N. (2005). Hormonal cycle modulates arousal circuitry in women using functional magnetic resonance imaging. J Neurosci, 25(40), 9309-9316. https://doi.org/10.1523/jneurosci.2239-05.2005

Goldstein, J. M., Seidman, L. J., Horton, N. J., Makris, N., Kennedy, D. N., Caviness, V. S., Jr., Faraone, S. V., \& Tsuang, M. T. (2001). Normal sexual dimorphism of the adult human brain assessed by in vivo magnetic resonance imaging. Cereb Cortex, 11(6), 490-497. https://doi.org/10.1093/cercor/11.6.490

Gouveia, F. V., Hamani, C., Fonoff, E. T., Brentani, H., Alho, E. J. L., de Morais, R., de Souza, A. L., Rigonatti, S. P., \& Martinez, R. C. R. (2019). Amygdala and Hypothalamus: Historical Overview With Focus on Aggression. Neurosurgery, 85(1), 11-30. https://doi.org/10.1093/neuros/nyy635

Hahn, A., Kranz, G. S., Sladky, R., Kaufmann, U., Ganger, S., Hummer, A., Seiger, R., Spies, M., Vanicek, T., Winkler, D., Kasper, S., Windischberger, C., Swaab, D. F., \& Lanzenberger, R. (2016). Testosterone affects language areas of the adult human brain. Hum Brain Mapp, 37(5), 1738-1748. https://doi.org/10.1002/hbm.23133

Hashikawa, K., Hashikawa, Y., Tremblay, R., Zhang, J., Feng, J. E., Sabol, A., Piper, W. T., Lee, H., Rudy, B., \& Lin, D. (2017). Esr1(+) cells in the ventromedial hypothalamus control female aggression. Nat Neurosci, 20(11), 1580-1590. https://doi.org/10.1038/nn.4644

Kranz, G. S., Hahn, A., Kaufmann, U., Küblböck, M., Hummer, A., Ganger, S., Seiger, R., Winkler, D., Swaab, D. F., Windischberger, C., Kasper, S., \& Lanzenberger, R. (2014). White matter microstructure in transsexuals and controls investigated by diffusion tensor imaging. J Neurosci, 34(46), 1546615475. https://doi.org/10.1523/jneurosci.2488-14.2014

Kranz, G. S., Hahn, A., Kaufmann, U., Tik, M., Ganger, S., Seiger, R., Hummer, A., Windischberger, C., Kasper, S., \& Lanzenberger, R. (2018). Effects of testosterone treatment on hypothalamic neuroplasticity in female-to-male transgender individuals. Brain Struct Funct, 223(1), 321-328.

https://doi.org/10.1007/s00429-017-1494-z

Kranz, G. S., Seiger, R., Kaufmann, U., Hummer, A., Hahn, A., Ganger, S., Tik, M., Windischberger, C., Kasper, S., \& Lanzenberger, R. (2017). Effects of sex hormone treatment on white matter microstructure in individuals with gender dysphoria. Neuroimage, 150, 60-67. https://doi.org/10.1016/j.neuroimage.2017.02.027

Kranz, G. S., Zhang, B. B. B., Handschuh, P., Ritter, V., \& Lanzenberger, R. (2020). Gender-affirming hormone treatment - A unique approach to study the effects of sex hormones on brain structure and function. Cortex, 129, 68-79. https://doi.org/10.1016/j.cortex.2020.04.005

Kristensen, T. T., Christensen, L. L., Frystyk, J., Glintborg, D., T'Sjoen, G., Roessler, K. K., \& Andersen, M. S. (2021). Effects of testosterone therapy on constructs related to aggression in transgender men: A systematic review. Hormones and 
medRxiv preprint doi: https://doi.org/10.1101/2022.02.02.22270319; this version posted February 4, 2022. The copyright holder for this preprint (which was not certified by peer review) is the author/funder, who has granted medRxiv a license to display the preprint in perpetuity.

It is made available under a CC-BY 4.0 International license .

Behavior, 128, 104912.

https://doi.org/https://doi.org/10.1016/j.yhbeh.2020.104912

Lee, H., Kim, D.-W., Remedios, R., Anthony, T. E., Chang, A., Madisen, L., Zeng, H., \& Anderson, D. J. (2014). Scalable control of mounting and attack by Esr1+ neurons in the ventromedial hypothalamus. Nature, 509(7502), 627-632. https://doi.org/10.1038/nature13169

Lenz, K. M., \& McCarthy, M. M. (2010). Organized for sex - steroid hormones and the developing hypothalamus. Eur J Neurosci, 32(12), 2096-2104. https://doi.org/10.1111/j.1460-9568.2010.07511.x

Makris, N., Swaab, D. F., van der Kouwe, A., Abbs, B., Boriel, D., Handa, R. J., Tobet, S., \& Goldstein, J. M. (2013). Volumetric parcellation methodology of the human hypothalamus in neuroimaging: Normative data and sex differences. Neuroimage, 69, 1-10. https://doi.org/https://doi.org/10.1016/j.neuroimage.2012.12.008

Nguyen, H. B., Loughead, J., Lipner, E., Hantsoo, L., Kornfield, S. L., \& Epperson, C. N. (2019). What has sex got to do with it? The role of hormones in the transgender brain. Neuropsychopharmacology, 44(1), 22-37. https://doi.org/10.1038/s41386-018-0140-7

Paredes, R. G. (2003). Medial preoptic area/anterior hypothalamus and sexual motivation. Scand J Psychol, 44(3), 203-212. https://doi.org/10.1111/14679450.00337

Pol, H. E. H., Cohen-Kettenis, P. T., Van Haren, N. E. M., Peper, J. S., Brans, R. G. H., Cahn, W., Schnack, H. G., Gooren, L. J. G., \& Kahn, R. S. (2006). Changing your sex changes your brain: influences of testosterone and estrogen on adult human brain structure. European Journal of Endocrinology eur $j$ endocrinol, 155(suppl_1), S107-S114. https://doi.org/10.1530/eje.1.02248

Protopopescu, X., Butler, T., Pan, H., Root, J., Altemus, M., Polanecsky, M., McEwen, B., Silbersweig, D., \& Stern, E. (2008). Hippocampal structural changes across the menstrual cycle. Hippocampus, 18(10), 985-988.

Reuter, M., Schmansky, N. J., Rosas, H. D., \& Fischl, B. (2012). Within-subject template estimation for unbiased longitudinal image analysis. Neuroimage, 61(4), 1402-1418. https://doi.org/10.1016/j.neuroimage.2012.02.084

Salk, R. H., Hyde, J. S., \& Abramson, L. Y. (2017). Gender differences in depression in representative national samples: Meta-analyses of diagnoses and symptoms. Psychol Bull, 143(8), 783-822. https://doi.org/10.1037/bul0000102

Saper, C. B., \& Lowell, B. B. (2014). The hypothalamus. Current Biology, 24(23), R1111-R1116. https://doi.org/https://doi.org/10.1016/j.cub.2014.10.023

Schindler, S., Geyer, S., Strauß, M., Anwander, A., Hegerl, U., Turner, R., \& Schönknecht, P. (2012). Structural studies of the hypothalamus and its nuclei in mood disorders. Psychiatry Res, 201(1), 1-9. https://doi.org/10.1016/j.pscychresns.2011.06.005

Schindler, S., Schmidt, L., Stroske, M., Storch, M., Anwander, A., Trampel, R., Strauß, M., Hegerl, U., Geyer, S., \& Schönknecht, P. (2019). Hypothalamus enlargement in mood disorders. Acta Psychiatr Scand, 139(1), 56-67. https://doi.org/10.1111/acps.12958

Seiger, R., Hahn, A., Hummer, A., Kranz, G. S., Ganger, S., Woletz, M., Kraus, C., Sladky, R., Kautzky, A., Kasper, S., Windischberger, C., \& Lanzenberger, R. (2016). Subcortical gray matter changes in transgender subjects after longterm cross-sex hormone administration. Psychoneuroendocrinology, 74, 371379. https://doi.org/10.1016/j.psyneuen.2016.09.028 
medRxiv preprint doi: https://doi.org/10.1101/2022.02.02.22270319; this version posted February 4, 2022. The copyright holder for this preprint (which was not certified by peer review) is the author/funder, who has granted medRxiv a license to display the preprint in perpetuity

It is made available under a CC-BY 4.0 International license.

Spies, M., Hahn, A., Kranz, G. S., Sladky, R., Kaufmann, U., Hummer, A., Ganger, S., Kraus, C., Winkler, D., Seiger, R., Comasco, E., Windischberger, C., Kasper, S., \& Lanzenberger, R. (2016). Gender transition affects neural correlates of empathy: A resting state functional connectivity study with ultra high-field 7T MR imaging. Neuroimage, 138, 257-265.

https://doi.org/10.1016/j.neuroimage.2016.05.060

Swaab, D. F., Hofman, M. A., Lucassen, P. J., Purba, J. S., Raadsheer, F. C., \& Van de Nes, J. A. P. (1993). Functional neuroanatomy and neuropathology of the human hypothalamus. Anatomy and Embryology, 187(4), 317-330. https://doi.org/10.1007/BF00185889

Timper, K., \& Brüning, J. C. (2017). Hypothalamic circuits regulating appetite and energy homeostasis: pathways to obesity. Dis Model Mech, 10(6), 679-689. https://doi.org/10.1242/dmm.026609

Zhao, Z. D., Yang, W. Z., Gao, C., Fu, X., Zhang, W., Zhou, Q., Chen, W., Ni, X., Lin, J. K., Yang, J., Xu, X. H., \& Shen, W. L. (2017). A hypothalamic circuit that controls body temperature. Proc Natl Acad Sci U S A, 114(8), 2042-2047. https://doi.org/10.1073/pnas.1616255114

Zubiaurre-Elorza, L., Junque, C., Gómez-Gil, E., \& Guillamon, A. (2014). Effects of cross-sex hormone treatment on cortical thickness in transsexual individuals. $J$ Sex Med, 11(5), 1248-1261. https://doi.org/10.1111/jsm.12491 